\title{
EL SUICIDIO DE EUROPA. LA DECADENCIA DEL CAMPO, EL AUGE DE LA PORNOGRAFÍA Y DEL HOMBRE MASA
}

\author{
Carlos Javier Blanco Martín \\ Universidad de Oviedo
}

Resumen: En este ensayo, de la mano de Oswald Spengler, pasamos revista a la decadencia de la civilización europea tomando como guía tres fenómenos: el análisis de las relaciones entre el campo y la gran ciudad, el advenimiento de la una sociedad hipererotizada y pornográfica, así como el predominio del hombre masa.

Palabras clave: decadencia, Europa, relaciones campo-ciudad, pornografía, hombre masa

The suicide of Europe. The decay of the country, the rise of pornography and mass-man

\begin{abstract}
Oswald Spengler, we review the decline of European civilization. For this we have to be guided by three phenomena: the analysis of the relationships between rural and big city, the advent of a pornographic overerotic society, and the dominance of the mass-man.
\end{abstract}

Keywords: decay, Europe, rural-urban relationships, pornography, mass man

\section{Introducción}

En este ensayo meditaremos sobre Occidente. Lo haremos de la mano de Oswald Spengler principalmente, pero sin olvidar a Nietzsche, Marx, Freud, Fromm y otros grandes pensadores. El filósofo germano, genial autor de La Decadencia de Occidente, vaticinó, entre el estruendo de los tambores de guerra que asolaban Europa a comienzos del siglo $X X$, la muerte de nuestra civilización y la necesidad de librar por medio de una guerra expansiva las últimas posibilidades de una civilización vieja, presta a convertirse en cadáver y tiempo ha reducida a fósil de formas caducas. El pluralismo cultural de Spengler supone el fin de las abstracciones vacías: Humanidad, al igual que Progreso o Libertad, Igualdad o Fraternidad, son esos nuevos dioses fríos y abstractos, que no reclaman sino tibia devoción y que resultan tan caducos como la propia Modernidad que los creó. Los ideales de la llustración y de la Revolución conspiraron con la cosificación del hombre en el industrialismo y prepararon el paisaje de una Europa de fábricas, de "mano de obra" y de urbes mundiales absolutamente artificiales, desconectadas progresivamente de la cultura que les precedió. 
Pero «la humanidad» no tiene un fin, una idea, un plan; como no tiene fin ni plan la especie de las mariposas o de las orquídeas. «Humanidad» es un concepto zoológico o una palabra vana, Que desaparezca este fantasma del círculo de problemas referentes a la forma histórica, y se verán surgir con sorprendente abundancia las verdaderas formas.[LDO,I, 51] $]^{1}$

\section{"Humanidad": idea abstracta}

No existe la Humanidad. Solamente tenemos ante la mirada una pluralidad de culturas y civilizaciones. Unas son jóvenes, otras viejas. Cada cultura es un organismo viviente. La civilización es un cadáver que progresivamente abandona su vitalidad y fosiliza sus formas. No hay un fin (Ziel) en la Humanidad, y por ello los ideales por los que se luchó en la Revolución Francesa, como en tantas otras revoluciones que le siguieron, fueron coyunturales y específicos de una determinada fase de la cultura Occidental, a punto de entrar en la fase de cadavérica civilización. Libertad, Igualdad y Fraternidad proclamadas, no ya en nombre del ciudadano (francés) sino del Hombre, son ahora, en el ocaso de Occidente, meras abstracciones que han servido apenas al propósito de colonizar a los bárbaros, a los no europeos. Ya que no hay colonias, y los bárbaros se han metido en casa, Europa aparece decrépita, con su "Humanidad" vacía de significado. Todo andaba muy bien cuando "Humanidad" connotaba "blanco", "cristiano", "europeo". Pero la Historia ha seguido su curso, y ahora la abstracción se ha vuelto en contra de la cultura que la engendró.

Hay aquí una insondable riqueza, profundidad y movilidad de lo viviente, que hasta ahora ha permanecido oculta bajo una frase vacía, un esquema seco, o unos «ideales» personales. En lugar de la monótona imagen de una historia universal en línea recta, que sólo se mantiene porque cerramos los ojos ante el número abrumador de los hechos, veo yo el fenómeno de múltiples culturas poderosas, que florecen con vigor cósmico en el seno de una tierra madre, a la que cada una de ellas está unida por todo el curso de su existencia. [LDO, I, $51]^{2}$

\footnotetext{
${ }^{1}$ [A partir de ahora, las citas de La Decadencia de Occidente se harán de la siguiente manera: LDO, I significa tomo primero de la versión castellana de la obra, en la traducción de Manuel G. Morente, Editorial Espasa, Madrid, 2011. Las citas de la versión alemana, DUA, son las iniciales de Der Untergang des Abendlandes, Edición de Beck, Munich, 1923]
}

Aber «die Menschheit» hat kein Ziel, keine Idee, keinen Plan, so wenig wie die Gattung der Schmetterlinge oder der Orchideen ein Ziel hat. »Die Menschheit« ist ein zoologischer Begriff oder ein leeres Wort. Man lasse dies Phantom aus dem Umkreis der historischen Formprobleme schwinden und man wird einen überraschenden Reichtum wirklicher Formen auftauchen sehen. [DUA, I, 28].

${ }^{2}$ Hier ist eine unermeßliche Fülle, Tiefe und Bewegtheit des Lebendigen, die bis jetzt durch ein Schlagwort, durch ein dürres Schema, durch persönliche «Ideale» verdeckt wurde. Ich sehe statt jenes öden Bildes einer linienförmigen Weltgeschichte, das man nur aufrecht erhält, wenn man vor der überwiegenden Menge der Tatsachen das Auge schließt, das Schauspiel einer Vielzahl mächtiger Kulturen, die mit urweltlicher Kraft aus dem Schöße einer mütterlichen Landschaft, an die jede von ihnen im ganzen Verlauf ihres Daseins streng gebunden ist...[DUA,I, 29]. 
La historia de los organismos llamados culturas ofrece el espectáculo teatral (Schauspiel) de su nacimiento, florecer y declive, que llega hasta la muerte. Cada cultura goza de una fuerza cósmica primigenia (urweltlicher Kraft), que se puede ampliar o angostar en su decurso, tal y como acontece en los individuos. Y si los rasgos de cada especie han de entenderse en relación al hábitat en el que ésta vive, lo mismo tenemos que decir de las culturas. Estas nacen de una Tierra de donde cobran un boceto primigenio, por más que después se sucedan migraciones, desplazamientos, incrustaciones, etc. la Tierra Madre le brinda un rostro a la cultura que nace. Las culturas son anteriores y posteriores al Estado, y a menudo deben sobrevivirle. Los Estados son productos efímeros de este jardín abigarrado que se da en llamar "Historia Universal", y además su factura es de lo más heterogénea. Desde la polis griega, al Imperio Oriental, desde el reino feudal o el Sacro Imeprio Romano Germánico. Desde la monarquía absoluta barroca de Europa, hasta el "Estado Nación" del siglo XIX...Las repúblicas o los sultanatos, la monarquía parlamentaria o la autocracia...Los Estados son producto de la más efímera coyuntura, resultado de la contingencia. Incluso los Imperios chino y romano, arquetipos de cuasieternidad política, no constituyen una unidad esencial. El tiempo no admite la ilusión de una estabilidad espacial. La pseudomorfosis, esto es, la permanencia espacial de formas civilizadas rígidas, habla por sí misma del poder del Tiempo. El Tiempo niega la ilusión de que los romanos del tiempo de San Agustín sean los mismos que los de tiempos de Augusto. Muchas pseudomorfosis se conservaban cuando poco después cayó Roma, pero solamente éstas.

De más larga permanencia es la comarca (Landschaft). Los pueblos se amamantan de su región materna, aunque después discurran por toda clase de superficies.

Cada una de esas culturas imprime a su materia, que es el hombre, su forma propia; cada una tiene su propia idea, sus propias pasiones, su propia vida, su querer, su sentir, su morir propios. Hay aquí colores, luces, movimientos, que ninguna contemplación intelectual ha descubierto aún. Hay culturas, pueblos, idiomas verdades, dioses, paisajes, que son jóvenes y florecientes; otros que son ya viejos y decadentes; como hay robles, tallos, ramas, hojas, flores, que son viejos y otros que son, jóvenes. Pero no hay «humanidad» vieja. Cada cultura posee sus propias posibilidades de expresión, que germinan, maduran, se marchitan y no reviven jamás. [LDO, I, 51] $]^{3}$

\footnotetext{
${ }^{3}$ [...] von denen jede ihrem Stoff, dem Menschentum, ihre eigne Form aufprägt, von denen jede ihre eigne Idee, ihre eignen Leidenschaften, ihr eignes Leben, Wollen, Fühlen, ihren eignen Tod hat Hier gibt es Farben, Lichter, Bewegungen, die noch kein geistiges Auge entdeckt hat. Es gibt aufblühende und alternde Kulturen, Völker, Sprachen, Wahrheiten, Götter, Landschaften, wie es junge und alte Eichen und Pinien, Blüten, Zweige und Blätter gibt, aber es gibt keine alternde »Menschheit«. Jede Kultur hat ihre neuen Möglichkeiten des Ausdrucks, die erscheinen, reifen, verwelken und nie wiederkehren.[DUA,I, 29]
} 
¿Hace el hombre su propia historia, como decía Marx? Aquí, en Spengler vemos más bien que es el hombre la materia pasiva que resulta moldeada por la cultura o civilización en la que nace y vive. Aquí el hombre es materia (Stoff), y no agente de la Historia. Está sometido a los ciclos y ritmos periódicos de la Historia, que Spengler concibe como una suerte de Supranaturaleza. La propia Naturaleza es Historia. La intuición de la misma ha de practicarse al modo de Goethe, no al modo de Newton. La Historia obliga al hombre a actuar desde dentro de una cultura. Es en la cultura donde hay una necesidad de índole morfológica que imprime los cauces de posibles desarrollos. Cada cultura se abre a determinadas posibilidades de expresión [Jede Kultur hat ihre neuen Möglichkeiten des Ausdrucks]. Cuando estas posibilidades se angostan, hablamos de muerte, por analogía con el fin de la vida de un individuo, aunque lo que sucede en realidad es un no retorno. La cultura, como el organismo, no puede seguir "circulando", regulando sus ciclos. Se da una parálisis, se marchita y no hay retorno [verwelken und nie wiederkehren].

Toda cultura es una pluralidad de facetas, de expresiones:

Hay muchas plásticas muy diferentes, muchas pinturas, muchas matemáticas, muchas físicas; cada una de ellas es, en su profunda esencia, totalmente distinta de las demás; cada una tiene su duración limitada; cada una está encerrada en sí misma, como cada especie vegetal tiene sus propias flores y sus propios frutos, su tipo de crecimiento y de decadencia. Esas culturas, seres vivos de orden superior, crecen en una sublime ausencia de todo fin $y$ propósito, como flores en el campo. Pertenecen, cual plantas y animales, a la naturaleza viviente de Goethe, no a la naturaleza muerta de Newton. Yo veo en la historia universal la imagen de una eterna formación y deformación, de un maravilloso advenimiento y perecimiento de formas orgánicas. El historiador de oficio, en cambio, concibe la historia a la manera de una tenia que, incansablemente, va añadiendo época tras época. [LDO, I, 51-52]

Ya fue Vico, en el siglo XVIII, quien supo ver en la Historia un progreso y un regreso, un curso de avance y un retorno. Con los nubarrones de guerra mundial encima de las cabezas del occidental, y con el advenimiento de unos años duros de guerra expansiva por parte de las potencias (la guerra expansiva era última posibilidad de actuación para los alemanes, según Spengler), debemos comprender el sino de Europa: estamos en la fase de declive (Untergang, Niedergang). Las explicaciones deterministas, economicistas, etc., propias del materialismo histórico, por ejemplo, y de otras corrientes, como el positivismo, no sirven para barruntar el ciclo completo en el que vivimos

\footnotetext{
${ }^{4}$ Es gibt viele, im tiefsten Wesen völlig voneinander verschiedene Plastiken, Malereien, Mathematiken, Physiken, jede von begrenzter Lebensdauer, jede in sich selbst geschlossen, wie jede Pflanzenart ihre eigenen Blüten und Früchte, ihren eignen Typus von Wachstum und Niedergang hat. Diese Kulturen, Lebewesen höchsten Ranges, wachsen in einer erhabenen Zwecklosigkeit auf wie die Blumen auf dem Felde. Sie gehören, wie Pflanzen und Tiere, der lebendigen Natur Goethes, nicht der toten Natur Newtons an. Ich sehe in der Weltgeschichte das Bild einer ewigen Gestaltung und Umgestaltung, eines wunderbaren Werdens und Vergehens organischer Formen. Der zünftige Historiker aber sieht sie in der Gestalt eines Bandwurms, der unermündlich Epochen «ansetzt».
} 
nosotros y nuestros ancestros. Tampoco son de validez para reconocer la ineluctable caída en la que nos hayamos. Corsi e ricorsi, en palabras de Vico: la historia de una cultura implica una formación y una deformación [Gestaltung und Umgestaltung].

La europeidad no es eterna. Los valores de lo occidental se diluyen. Son muchos los detonantes: contracción de su expansión colonial, la multiculturalidad de sus sociedades, la primacía de la gran urbe desarraigada frente a "la región" (Landschaft). Pero estos detonantes se subordinan en todo caso a la necesidad morfológica. Culturas jóvenes y fuertes que ahora se sumergen en la oscuridad, esperan pacientes el turno para tomar su protagonismo y hacer caer el edificio viejo, fosilizado, el de la Europa cadavérica. Spengler sabía que otras culturas ocuparían el centro.

La decadencia de Occidente, considerada así, significa nada menos que el problema de la civilización. Nos hallamos frente a una de las cuestiones fundamentales de toda historia. ¿Qué es «civilización», concebida como secuencia lógica, como plenitud y término de una «cultura»?. Porque cada «cultura» tiene su «civilización» propia. Por primera vez tómanse aquí estas dos palabras - que hasta ahora designaban una vaga distinción ética de índole personal - en un sentido periódico, como expresiones de una orgánica sucesión estricta y necesaria. La «civilización» es el inevitable sino de toda «cultura». Hemos subido a la cima desde donde se hacen solubles los últimos y más difíciles problemas de la morfología histórica. «Civilización» es el extremo y más artificioso estado a que puede llegar una especie superior de hombres. Es un remate; subsigue a la acción creadora como lo ya creado, lo ya hecho, a la vida como la muerte, a la evolución como el anquilosamiento, al campo y a la infancia de las almas - que se manifiesta, por ejemplo, en el dórico y en el gótico - como la decrepitud espiritual y la urbe mundial petrificada y petrificante. Es un final irrevocable, al que se llega siempre de nuevo, con íntima necesidad. (LDO, I, 64-65) ${ }^{5}$

De la cultura, se sigue necesariamente -con necesidad lógica y orgánica- la civilización. La civilización que corresponde a cada cultura, como estado al que ésta ha de llegar, es única. De la misma manera que no existe el Hombre (abstracto), tampoco hay pábulo para la Civilización (abstracta). A cada cultura le está reservada su civilización. Esta es el destino que le está reservado [Die

\footnotetext{
${ }^{5}$ Der Untergang des Abendlandes, so betrachtet, bedeutet nichts Geringeres als das Problem der Zivilisation. Eine der Grundfragen aller höheren Geschichte liegt hier vor. Was ist Zivilisation, als organisch-logische Folge, als Vollendung und Ausgang einer Kultur begriffen? Denn jede Kultur hat ihre eigne Zivilisation. Zum ersten Male werden hier die beiden Worte, die bis jetzt einen unbestimmten Unterschied ethischer Art zu bezeichnen hatten, in periodischem Sinne, als Ausdrücke für ein strenges und notwendiges organisches Nacheinander gefaßt. Die Zivilisation ist das unausweichliche Schicksal einer Kultur. Hier ist der Gipfel erreicht, von dem aus die letzten und schwersten Fragen der historischen Morphologie lösbar werden. Zivilisationen sind die äußersten und künstlichsten Zustände, deren eine höhere Art von Menschen fähig ist. Sie sind ein Abschluß; sie folgen dem Werden als das Gewordene, dem Leben als der Tod, der Entwicklung als die Starrheit, dem Lande und der seelischen Kindheit, wie sie Dorik und Gotik zeigen, als das geistige Greisentum und die steinerne, versteinernde Weltstadt. Sie sind ein Ende, unwiderruflich, aber sie sind mit innerster Notwendigkeit immer wieder erreicht worden. [DUA,I, 43].
} 
Zivilisation ist das unausweichliche Schicksal einer Kultur] de una forma ineluctable. $Y$ de este carácter relativo a cada cultura debe decantarse un resultado absoluto: siempre hay decadencia en un devenir, y siempre hay una hora del fin. La Europa otoñal va a quedar expuesta a fuertes vientos de la historia. Las hojas cubrirán sus monumentos, junto con la desidia y la falta de educación. Los hombres cultos (en sentido spengleriano) pasan ya por locos o infelices, ante el alegre bullicio del civilizado, es decir, del que se postra ante esa molicie colectiva que representa para todos nosotros el consumo, la finanzas, el multiculturalismo y la bolsa, las novedades tecnológicas y los brutales espectáculos de masa. El hombre de cultura se retira de la escena, a la que ya no reconoce suya, pues Europa ya no es su casa. Se extingue, se volatiliza. Pero el hombre de masa civilizada disfruta del consumo de un ocio y de unos servicios que malamente disimulan la prostitución, la esclavitud y el crimen. Todo ello pasa a ser "divertido". Este sino (Schicksal) no es percibido por el hombre masa, y menos aún se puede captar en los albores. El poder del sino puede barruntarse con esta filosofía en la que la propia Naturaleza es un capítulo de la Historia, pero una Historia en la que no cuenta el capricho de secuencias de hechos, el azar, la contingencia. Se trata de una filosofía de la historia donde hay una muy alta y poderosa necesidad (Notwendigkeit).

El tránsito de la «cultura» a la «civilización» se lleva a cabo, en la Antigüedad, hacia el siglo IV; en el Occidente, hacia el XIX. A partir de estos momentos, las grandes decisiones espirituales no se toman ya "en el mundo entero», como sucedía en tiempos del movimiento órfico y de la Reforma, en que no había una sola aldea que no tuviese su importancia. Ahora tómanse esas decisiones en tres o cuatro grandes urbes que han absorbido el jugo todo de la historia, $y$ frente a las cuales el territorio restante de la cultura queda rebajado al rango de «provincia»; la cual, por su parte, no tiene ya otra misión que alimentar a las grandes urbes con sus restos de humanidad superior. iCiudad mundial y provincia! .Estos dos conceptos fundamentales de toda civilización plantean ahora para la historia un nuevo problema de forma. Estamos viviéndolo justamente los hombres de hoy, sin haberlo comprendido, ni siquiera de lejos, en todo su alcance. En lugar de un mundo tenemos una ciudad, un punto, en donde se compendia la vida de extensos países, que mientras tanto se marchitan. En lugar de un pueblo lleno de formas, creciendo con la tierra misma, tenemos un nuevo nómada, un parásito, el habitante de la gran urbe, hombre puramente atenido a los hechos, hombre sin tradición, que se presenta en masas informes y fluctuantes; hombre sin religión, inteligente, improductivo, imbuido de una profunda aversión a la vida agrícola - y su forma superior, la nobleza rural -, hombre que representa un paso gigantesco hacia lo inorgánico, hacia el fin. [LDO, I, 66] ${ }^{6}$

\footnotetext{
${ }^{6}$ Der Übergang von der Kultur zur Zivilisation vollzieht sich in der Antike im 4., im Abendland im 19. Jahrhundert. Von da an fallen die großen geistigen Entscheidungen nicht mehr wie zur Zeit der orphischen Bewegung und der Reformation in der »ganzen Welt«, in der schließlich kein Dorf ganz unwichtig ist, sondern in drei oder vier Weltstädten, die allen Gehalt der Geschichte in sich aufgesogen haben und denen gegenüber die gesamte Landschaft einer Kultur zum Range der Provinz herabsinkt, die ihrerseits nur noch die Weltstädte mit den Resten ihres höheren Menschentums zu nähren hat. Weltstadt und Provinz - mit diesen Grundbegriffen jeder Zivilisation tritt ein ganz neues Formproblem der Geschichte hervor, das wir Heutigen gerade durchleben, ohne es in seiner ganzen Tragweite auch nur entfernt begriffen zu haben. Statt einer Welt eine Stadt, ein Punkt, in dem sich das ganze Leben weiter Länder sammelt,
} 


\section{La dialéctica entre el campo y la ciudad}

La dialéctica entre "campo" (Landschaft) y "urbe" (Welstadt) es magistralmente señalada por Oswald Spengler. En contra de las tendencias de muchos marxistas y demás filósofos de la historia devotos del Progreso, el "campo" o "la comarca" representa la "humanidad superior" [den Resten ihres höheren Menschentums]. Precisamente porque ya no es su mundo, el habitante cosmopolita de las gradnes urbes no entiende esa superioridad, y la desprecia porque la ignora. La vida de la aldea, y el paisaje rural que circunda las ciudades representan en su mente un pasado superviviente que espera morir en aras de una ciudad industrial y cosmopolita. El cosmopolita no soporta el campo ni sus valores como no sea en términos de colonización urbana: como granero, como parque para el ocio, como vertedero, como solar para nuevas residencias. El capitalismo tardío no se puede dar sin la completa subordinación de la "comarca" (aldea, provincia, región) a los centros capitalinos de decisión. Es así materialmente, pues al campo no se le reconoce ya autonomía, es la periferia colonizada desde un centro, pero también sucede lo mismo en un plano simbólico. El campo, el aldeano, la supervivencia misma de formas de vida nobles, tradicionales, basadas en una economía originaria, no pueden significar otra cosa que un insulto para el hombre sin raíces de la gran ciudad. Éste se siente agredido en lo más profundo de su subconsciente. La sana y noble vida campesina, su misma organicidad, le dice al "inteligente" ciudadano cosmopolita: "no eres nada, careces de raíces". Por debajo de la guerra entre estados nacionales o imperios, late una guerra feroz y sorda, la guerra entre el campo la ciudad cosmopolita. En el medievo y hasta la industrialización incipiente de finales del siglo XVII la ciudad todavía era un complemento de la granja y la aldea: mercado, administración, festividad, rito. Era espacio público necesario para dar riqueza al aislado campesino. Pero la industria y, hoy, la creación de grandes urbes dilapidadoras, no han hecho otra cosa que inclinar la balanza en contra de la periferia rural. Ora domesticando la producción agrícola, subordinándola a las necesidades de la urbe, ora arrinconándola, la ciudad domina y mata al campo. El arrinconamiento sucede cuando ésta colonización no es rentable y se prefieren los graneros de países más lejanos. El caso es que hay una distancia cada vez mayor entre la mentalidad ciudadana cosmopolita y los valores tradicionales de aldeanos que se esconden apenas a unos kilómetros del centro de las capitales. Hay más cercanía y solidaridad, más cosmovisión compartida entre un madrileño cosmopolita y un neoyorquino de parecida instrucción y clase social, que entre éste capitalino y el aldeano más próximo a su capital. La distancia espacial ya no indica nada. Hace unas décadas esto todavía no era así: las ciudades de países poco desarrollados eran permeables: las corrientes migratorias que nutrían sus barrios y sus clases obreras procedían del propio cinturón rural de las mismas. Los emigrantes no venían de tan lejos. La ficción de los "estados-

während der Rest verdorrt; statt eines formvollen, mit der Erde verwachsenen Volkes ein neuer Nomade, ein Parasit, der Groß Stadtbewohner, der reine, traditionslose, in formlos fluktuierender Masse auftretende Tatsachenmensch, irreligiös, intelligent, unfruchtbar, mit einer tiefen Abneigung gegen das Bauerntum (und dessen höchste Form, den Landadel), also ein ungeheurer Schritt zum Anorganischen, zum Ende - was bedeutet das? [DUA,I, 44]. 
nación" pudo sostenerse desde el siglo XIX gracias a este proceso. Al igual que afluían las verduras de los huertos de la campiña circundante, afluían también las manos fuertes del aldeano forzado o presto a proletarizarse. Hubo una fase efímera en la historia de toda gran urbe en que su savia se reforzaba y saneaba con tal emigración próxima. A medida que se urbaniza la propia aldea, a medida que se transforma en zona residencial o cinturón de industrias, a medida que el paisaje se degrada y se esclaviza, engullido por las necesidades crecientes de plusvalía, esa savia ya no se renueva y hay que buscarla progresivamente más lejos.

El hombre cosmopolita aborrece la vida agrícola. El obrero fabril del mundo opulento, habitante de la barriada, no de la ciudad mundial, todavía mantenía un pie en la campiña, de donde hacía poco había surgido. Pero el hombre civilizado, el decadente, ya ha roto sus raíces de la tierra de donde ha venido. Carece de linaje y de vínculos terráqueos. Por ello el decadente tiende, colectivamente y como promedio, hacia la Muerte. La civilización, al sentirse vieja, sueña con ella. El cansancio vital de la vida civilizada exige imperiosamente el suicidio, la eutanasia, el aborto y el infanticidio. La muerte de Europa, y en su conjunto, de todo el Occidente se manifiesta, en primer lugar y fundamentalmente, en una muerte demográfica. El profundo significado de que las parejas no quieran tener niños estriba en esta oscura intuición del sino. A todas las civilizaciones del pasado, en su angostamiento de posibilidades, en su cansancio, les ocurrió el mismo proceso: tras una educación muelle, donde la voluntad se afloja y la lascivia se desvincula de la reproducción y goza las cotas de espectáculo y de modo de vida (en el sexo acontece lo mismo que en el arte decadente: cobra autonomía, "el arte por el arte"). La muerte de Europa es muerte demográfica, pero también es deseo de destrucción, suicidio y sadomasoquismo. Sigmund Freud habló del impulso destructivo y aniquilador del hombre, el Tánatos, como esa tendencia regresiva hacia lo inorgánico.

\section{Civilización pornográfica}

El mundo occidental de hoy es un mundo pornográfico. Esta es la esencia última y radical de un modo de producción capitalista decadente, ya en su fase monopolista e imperial. De este modo de producción deriva una cosificación de la especie humana, de un grado elevadísimo en comparación con la cosificación alcanzada en momentos históricos previos, p.e., el Imperio Romano o la Colonización del mundo en el siglo XIX.

Se trata de la cosificación del ser humano, su conversión en objeto de consumo, uso, manipulación, entregado al consumo como medio y nunca fin en sí mismo. Se ha asentado en nuestro mundo el Imperativo Categórico al revés, un mandato antikantiano que rezaría así: "obra de tal modo que uses a la humanidad, tanto en tu persona como en la de los demás, siempre como un medio y nunca un fin en sí mismo".

El mejor testimonio cultural del proceso de cosificación lo tenemos en el campo de la pornografía. En muchos sentidos, el uso, el consumo y la 
comercialización de lo obsceno se ha extendido, ha aflorado, saliendo a la luz, ha colonizado amplios campos de la vida humana, más allá del estrictamente erótico y genital.

De todos es conocido el tropel de imágenes horrendas que salieron de la prisión iraquí de Abu-Grahib. Los presos, desnudados, se amontonan en forma de simples cuerpos, masa humana despojada de dignidad ante militares americanos uniformados. En aquellas fotos, la desnudez humana significaba estrictamente el despojamiento de poder y dignidad ante quien tenía "la sartén por el mango", frase hecha cuyos contenidos freudianos no se precisan explicitar más. La cópula simulada ante las cámaras, una cópula masiva y forzada, el arrastrarse por los suelos, sujetados por una correa y collar, al modo de los perros y bestias, el disparo simulado de aquella mujer soldado americana, con los dedos apuntados hacia los iraquíes indefensos y convertidos éstos en objeto de placer vinculado a la humillación y a la inevitabilidad de la derrota. Todas estas imágenes deben ser objeto de análisis y explicación exhaustiva. Así como la fotografía de los perros fieros ante pelotones de humanos indefensos y anulados en su misma humanidad, y demás exhibiciones de lo que es el Poder ante unos cuerpos humanos borrados en su humanidad esencial, más que alienados, cosificados hasta el punto de ser reducidos a ser carne humana simplemente.

¿A qué vienen estas imágenes de Abu-Grahib? ¿Son solamente un ejemplo de "abuso de los derechos humanos"? Fue un grave abuso en los derechos humanos de aquellas personas, evidentemente, uno más a añadir a los miles de ejemplos que nos ofrece la historia. La historia de una humanidad en la que los primeros imperios y ciudades-estado en la fase "civilizada" se dedicaban a cazar prisioneros y domesticarlos, como antes se había practicado con otras especies animales. La historia de la guerra y del estado es la historia de este animal de rapiña, el ser humano, en la que se violaban sistemáticamente a las mujeres del vencido, se castraba y se mutilaba al derrotado, se le reducía a la condición de esclavo, esto es, ganado y mercancía. Ni el cristianismo ni ningún otro evangelio de amor ha reducido o extinguido esa constante humana que es la del "abuso" de la humanidad, la del otro humano, especialmente. Y es que el hombre es un animal de rapiña.

La esclavitud, lejos de abolirse, regresa con fuerza en nuestro siglo XXI. Millones de mujeres y de niños son objeto de comercialización sexual en un mundo no ya consumista en este sentido, sino más bien voraz. El Reino de España es, dentro de la Unión Europea, uno de los mayores mercados de mercancía humana. Por otro lado, la degradación del trabajo asalariado a escala mundial hace que las condiciones de existencia de millones de personas se acerquen a las de la esclavitud estricta.

La sociedad de consumo que implica este capitalismo imperialista y monopolista acentúa las tendencias sado-masoquistas, como ya dejaron ver las investigaciones de la Escuela de Frankfurt, y muy especialmente Erich Fromm. En el sado-masoquismo, se bloquea y hasta se destruye toda capacidad de amor, y las pulsiones humanas van encaminadas hacia la 
destrucción del objeto, hacia el regodeo y la fruición en la aniquilación y sufrimiento del otro y del propio yo.

Un somero estudio de la iconografía pornográfica, y en especial la del sadomasoquismo, ilustra de manera magnífica el catálogo de perversiones (en el sentido técnico de la psicología y psiquiatría, no en el sentido moralista) y fantasías sexuales de nuestra sociedad de consumo altamente alienada. Se trata de una sociedad altamente voyeurista, en la que las pulsiones más destructivas y posesivas se quedan bloqueadas por la presión del ambiente social y por causa de la interiorización de las normas morales vigentes en un momento dado. Pero al quedarse bloqueadas esas pulsiones, y al existir pocos cauces de sublimación en un modo de producción tan consumista, tan voraz, tiene lugar toda una producción fantástica que no es en absoluto desdeñable a la hora de comprender hoy el mundo, el capitalismo y la deshumanización.

En la iconografía pornográfica vigente, materializada en la realidad en horrores como los de Abu-Ghraib y en otras partes, se toman numerosos materiales estéticos y escénicos de la Historia. La sustitución de la seducción por la conquista, el amor por la violación, la libre entrega del cuerpo por el encadenamiento y la restricción, son elementos de la fantasía sado-masoquista que los pornógrafos han tomado de la historia. La esclavitud en el mundo clásico, con la extrema animalización y cosificación que para los humanos supone toda una escenificación que hoy, en otra época distinta, es añorada: el ser vendidos, comprados, encadenados, sometidos a todo tipo de capricho y arbitrariedades por un amo absoluto. Decimos bien "añorada", porque en la mente del ser humano el pasado nunca se olvida, permanece escondido de forma inconsciente, en un Inconsciente Colectivo, y es fuente inagotable de imágenes y fantasías por más que el sujeto que las produce jamás haya estudiado Historia como disciplina académica ni haya frecuentado libros de esta materia. Otros periodos y contextos, como los tormentos de la Inquisición , ya en la edad moderna, o las miserias de la trata de negros, en fechas todavía más recientes, son parte del material inconsciente que sirve a los propósitos de la fantasía de la dominación absoluta del cuerpo humano (el propio y el ajeno), y su conversión en cosa e instrumento al servicio del uso y del disfrute de un poseedor.

En un principio el capitalismo industrial clásico nació muy al margen de estos fenómenos sado-masoquistas, como medio de producción de plusvalía a través de la producción de mercancías. La fría producción y acumulación de plusvalía estuvo detrás de una superestructura moral de signo ascético y puritano (la "ética protestante" de Max Weber), marcando para décadas el tono de la clase burguesa, entregada "religiosamente" a la profesión del dinero. La moral proletaria trató, en aquellas fechas victorianas, de mantenerse fiel a sus orígenes rurales (todo proletario lleva en su inconsciente y en su pasado a un campesino dentro), bastante más desenvueltos en moral sexual, especialmente si lo comparamos con el burgués victoriano de las ciudades, pero sabido es que la burguesía hizo cuanto pudo por "colonizar" a sus nuevos esclavos, los proletarios. Luchó por colonizarlos moralmente, haciendo verdaderas campañas misioneras para conducirles hacia la monogamia, hacia el matrimonio consagrado, hacia la abstinencia sexual y alcohólica. 
Hoy, con el advenimiento de una sociedad opulenta en Occidente, basada en el consumo general de las masas, al menos en el llamado "Primer Mundo", a costa de la inanición y subhumanización de las tres cuartas partes de la especie, la antigua moral del "libertino", es decir, la anti-moral relativista, nihilista, hedonista o, más frecuentemente, utilitaria, se desparrama por entre capas de la población muy amplias, justamente entre trabajadores semicultos o poco formados (en comparación con sus predecesores del "librepensamiento") y acceden a servicios y bienes disponibles únicamente a través de sueldos altos, tiempo de ocio mercantilizado, relajación en la moral conyugal, atomización de las familias y mayor permisividad social hacia la soltería.

De no ser porque las condiciones económicas lo fomentan, estos cambios sociales apuntados arriba no hubieran existido, y decimos esto sin pretender incurrir en economicismo alguno. Más bien, con Foucault, nos preguntamos por qué el sexo, lejos de ser reprimido bajo el capitalismo industrial tardío y opulento (como pretendía Marcuse) resulta por el contrario "inflado", y ello sin perjuicio de la introducción compensatoria de otros mecanismos represivos, de limitaciones, de coerciones, pero dentro de una estimulación comercial del pansexualismo. Desde la publicidad hasta el arte, pasando por el ocio nocturno y la planificación del turismo, todo resulta ser sexo mercantilizado de una forma u otra.

Frente a la verdadera des-represión, des-inhibición, propia de una sociedad de productores libremente asociados y organizados bajo el principio de la ayuda mutua, la sociedad individualista y egocéntrica del capitalismo conlleva la introducción de canales de comercialización del cuerpo humano. Ejércitos de millones de seres racionales son convertidos en mercancía en el más estricto sentido del término. Un objeto con valor de uso y valor de cambio, un objeto del que poder obtener plusvalía puesto "a trabajar". La prostitución es explotación de los cuerpos humanos, y su alta conexión con la esclavitud se remonta a los orígenes de la civilización misma, del estado. De la misma manera que hemos recordado en otros trabajos que el Patriarcado es anterior al Capitalismo, pero que se reorganiza bajo éste, lo mismo podemos afirmar de otras formas de sometimiento, dominación y control de cuerpos humanos, infantiles o adultos, femeninos o masculinos. La prostitución aparece ya allí donde hay una sociedad basada en el cambio, en el comercio, aunque esta sociedad no sea todavía capitalista en sentido estricto. Y por ello, a fines del neolítico y con el auge de jefaturas militaristas y proto-estatales esta subordinación y esclavización de hembras ya tiene su lugar. Pero lo específico en el Capitalismo, y más todavía en el Capitalismo tardío (imperialista y monopolista) es que la comercialización y explotación de cuerpos humanos alcanza todas las modalidades posibles, dejando de ser un fenómeno entre marginal y complementario del matrimonio. La prostitución bajo el Capitalismo occidental deja de ser excrecencia del Sistema y se convierte en la esencia y raíz del mismo.

Aquí solamente he pretendido hacer unos apuntes de lo que podrían ser conexiones importantes entre capitalismo, sexo, pornografía y esclavismo en esta fase civilizada del capitalismo tardío (imperialista y monopolista) altamente cosificador. Es evidente que hay una conexión íntima entre la moral de los 
esclavos, la rebelión de los esclavos en materia de moral, como diría Nietzsche, y la inflación pornográfica que llega a todos los aspectos de la vida decadente de la civilización europea.

\section{Morfología de la Historia y Decadencia.}

Spengler afirma que una filosofía a la altura de nuestro tiempo es una filosofía que pueda poner ante la mirada una morfología de la historia. Los grandes de la filosofía moderna había ignorado o despreciado esta ciencia: Kant, Schopenhauer. Es preciso dejar de ser moderno. La Física-matemática no es la categoría central en torno a cuyo punto de gravedad orbite la totalidad de la filosofía. Hay que hacerse cargo de la nueva ciencia de la historia, de su específica morfología. Y en esa ciencia se necesita acostumbrar a la mente al método comparativo, entendiendo por comparación la búsqueda de correspondencias, de homologías. Los periodos pueden corresponderse analógicamente: nuestro periodo (iniciado hace un siglo, cuando Spengler publicó LDO) se corresponde perfectamente con la Antigüedad decadente. El hecho de que el último romano no supiera que su mundo, ya barbarizado, orientalizado y cristianizado, que su civilización llegaba a su fin, resulta de lo más significativo. Gozosamente vivía este último romano sus días postreros como quien cree que son eternos, dice Spengler. Nosotros, por el contrario, diferimos en un aspecto crucial: somos historicistas ya, a diferencia de Kant y de Schopenhauer. Somos más conscientes de que nuestra civilización llega a su fin, se muere. Contamos con la ventaja de haber estudiado los orígenes de Grecia, de Roma y de otros pueblos. Sabemos, porque tenemos una Arqueología, una Filología, una Historia, sabemos algunos detalles que revelan su nacimiento de entre una oscura masa de pueblos prehistóricos. Conocemos sobre todo los fogonazos culturales de unos pueblos que se forman a sí mismos. Ese aparecer en la Historia universal como mojones imprescindibles en el trayecto de las masas humanas indica la posesión de una especie de fuerza, un vigor orientado hacia sí mismos y hacia sus vecinos. Es vigor e intuición de la propia voluntad: esa savia que recorre un pueblo deviene en Cultura. Un pueblo construye su Cultura en la plenitud de sus fuerzas, en el anhelo de buscarse un destino. Pero cuando estas posibilidades ya han sido recorridas, cuando el vigor se ha gastado en múltiples realizaciones, llega secretamente -como una ladrona- la Decadencia: las formas generadas se encorsetan, se vuelven rígidos moldes y máscaras a los que habrán de atenerse las nuevas expresiones de una vida colectiva cada vez más senil. La Cultura decadente y fosilizada se llama Civilización. La Civilización bien puede entenderse como el paisaje de ruinas y cadáveres de una cultura muerta, paisaje que obstaculiza el desarrollo de una nueva cultura, primero balbuciente y después vigorosa.

\section{Nacimiento de Europa como Cultura Faústica}

La llamada cultura faústica apareció en Europa allá por el año 1000. Desde Covadonga, en las montañas asturianas, y desde Poitiers en tierra de francos, la espada frenó al islam, civilización mágica, que había incendiado a los 
pueblos de la pseudomorfosis antigua. Bizantinos, sirios, egipcios, persas... pueblos de lo más heterogéneo, cada uno portador de un rico pasado civilizado, languidecían bajo moldes tardorromanos y helenísticos que ya nada decían, carentes de valor a no ser como corsé de sus más antiguas civilizaciones. Antes de que los árabes salieran de su desierto, ellos ya vivían bajo la cueva mágica. El Islam llegó a ellos como el fósforo llega a la pólvora esparcida por el suelo. También el sur de España era parte esencial de esa romanidad tardía, una sociedad urbanizada y llena de fatigas, una región de latifundio que amasaba esclavos y capital, el complemento imperialista de una urbe depredadora de tierras y manos. Los mahometanos llegaron con el ímpetu de los pueblos buscadores de botín e insuflado de fanatismo propio del recién converso: fueron bereberes los principales invasores, subordinados a una elite árabe que los necesitaba, pero que los odiaba racialmente hasta el máximo. En cuanto los bereberes cumplieron su función invasora (en el fondo, una nueva invasión bárbara, esta vez procedente del sur) e hicieron desaparecer al civilizado reino godo.

Todo el proceso en el que Europa se despojó de sus pseudomorfosis tardorromanas, del cristianismo mágico, de los bárbaros ocasionales (mahometanos por el sur y oriente, vikingos por el norte, magiares por el centro) fue el proceso del despertar faústico. Añorando el perdido Toledo godo, los reyes astures en realidad iniciaron la nueva Europa, la Europa faústica. Las pequeñas construcciones de los reyes astures presagian -dentro de su radical originalidad y el entrecruzamiento de influencias- las magnas obras del románico, el gótico, el barroco. El reino de los astures, sucesores de Pelayo, así como el de los francos, con Carlomagno, constituyen ejemplos magníficos de cómo un pueblo y unos héroes forjan sin saber qué estaban forjando. Ni renacía Toledo en Covadonga, ni Roma en Aquisgrán. Lo que sucedía era que nacía un alma totalmente nueva. Las almas en estado balbuciente han de nacer en periferias escabrosas, desiertos, bosques. Pero luego bajan a las llanuras fértiles, asolan ciudades, expanden fronteras. La espada y unos corazones briosos detuvieron una invasión bárbara -los bereberes- en su vanguardia, pero que traía la pseudomorfosis mágica en la retaguardia. La Córdoba califal, en lo que no era oriental (mezquitas, harenes, eunucos) era romano tardío. Plebes urbanas y altamente alienadas, espíritu comercial y asceta (van de la mano), refinamiento, poesía, orgía. Al norte, en cambio, nacía Europa. Los reyes asturianos sojuzgaron o se ganaron a tribus vasconas para así enlazar con los francos y expedir así la Vía de Santiago. Un pasillo de cultura nueva y fresca que llevaba hasta Occidente a su parte más occidental, valga la redundancia.

El contraste entre la civilización mágica y la cultura faústica, ya a la altura del año 1000, vendrá perfectamente marcado por el río Duero. Todo el septentrión, tomando este accidente geográfico como referencia, es el ámbito del germanismo. Como decía don Claudio Sánchez-Albornoz, la sociedad cristiana que se forjó durante la llamada "Reconquista" era una sociedad más libre, aunque careciera de los lujos y refinamientos de Al-andalus. Las gentes peleaban para sobrevivir y poblar, y poblaban para volver a pelear. La tierra, el dinamismo demográfico, el afán de expander fronteras, todo eso les movía. En cambio, los islamitas recurrían a mercenarios y esclavos, y hacían de sus 
ciudades espacios "civilizados" para el harén, el mercado de cuerpos humanos, rebaños de eunucos y solaz de pederastas.

La cultura faústica fue joven en el medievo. Su altura $-y$ no su ensanchamiento, como diría Carl Jung- la contemplamos en el gótico de las grandes catedrales. Un ensanchamiento prematuro fueron las cruzadas (incluyendo la Reconquista española). Pero Europa, no la Antigua raíz (Hélade) sino la Europa cercana anímicamente, se elevó en esas agujas que captaban energía divina. Las agujas góticas parecen como querer deshacer las bóvedas de la cultura mágica. No se trata de sometimiento, de arrebujarse bajo la cúpula en la cual el dios encierra al hombre (la llamada alma mágica). Ahora hay que horadar la techumbre y buscar el cielo. De la catedral gótica a los telescopios renacentistas, y de éstos a la cosmología físico-matemática actual, solo hay pasos continuos de una misma alma que se afana por desplazar las fronteras del "mundo" más allá, con sed insaciable.

\section{Llega la Modernidad: entra la Decadencia. EI Hombre Masa}

Pero la Modernidad ha ido trayéndonos de vuelta viejos fantasmas. Con el auge del capitalismo, ese espíritu comercial que nació en Italia, esa cultura de tenderos, de mercachifles, el alma faústica reconcentró sus afanes en una infinitud no tanto cósmica sino de acumulación de capital. El capitalismo que en las urbes romanas o islamitas era una simple excrecencia del poder tributario, la acumulación de los comerciantes y terratenientes, se convirtió en modo de vida, en modo de producción. Cuando se produjo un traslado del capitalismo comercial al capitalismo productivo, momento en que el dueño del capital es también agente organizador de grandes talleres de manufactura, la comunidad rural europea ya estaba suficientemente atomizada. Los restos de feudalismo no sirvieron para arrogarse un nuevo papel jurídico efectivo de "protector de los pobres", si bien este papel de resistencia y defensa de las comunidades rurales fue asumido por ciertas Leyes de Pobres, seguros del antiguo régimen contra la depredación capitalista (K. Polanyi). Era de todo punto necesario aniquilar esas defensas paternalistas y esos residuos feudales para lograr lo que Karl Marx Ilamó Acumulación Originaria.

Las ciudades europeas crecieron, la hipertrofia de las barriadas obreras transformó la cultura: llegó el momento de dar paso a la civilización. Este paso significó la irrupción de las masas.

¿Por qué esta ciencia social? ¿Por qué esta filosofía de la historia? La respuesta estriba en la masa. El hombre-masa requiere de explicaciones para entender un fenómeno que consiste en él mismo. Él mismo como hecho bruto y radical. No es posible apenas alcanzar la distinción y el reconocimiento. Hay una igualdad demasiado evidente y ésta no consiste en los privilegios, en los preceptos jurídicos, en la realización del socialismo. Es la igualdad del vulgo desclasado y perdido, ajeno a toda lucha encaminada a conquistar la hegemonía. Ese vulgo constituye una red másica que abarca la totalidad social en Occidente desde los tiempos de la posguerra mundial y vive principalmente 
en el llamado mundo opulento. Opulencia, al menos, que duró hasta hoy mismo y que bien podrá tener sus días contados.

La masa que llenó antaño los espacios públicos y rugía con reivindicaciones ora económicas ora jurídicas es una masa que ha ido desapareciendo a pesar del florecer efímero de los "indignados" y de otras primaveras utópicas. La masa hoy es claramente solitaria y su participación en el todo es de signo claramente místico y mágico. Se realiza por gracia de los medios de comunicación masivos, que impiden el molesto contacto y contagio, que aíslan profilácticamente del roce y de los miasmas que proceden de los otros. Hay que sintonizar mágicamente con los otros pero también mantenerlos a la distancia debida. El ideal casto de una comunión de almas pero no de cuerpos se realiza por medio de las posibilidades tecnológicas de los satélites de TV y de internet.

El hombre masa ya no pide nada salvo un reconocimiento, si quiera sea en su condición de esclavo. Nada halagaba tanto a ciertos esclavos antiguos que el ser reconocidos como tales por su amo. La masa busca amo, y cuando carece de él se torna rugiente y fiera: busca un Führer y hasta se lo inventa, pero la masa es ella misma espíritu obediente y, sin líderes ni canales mediáticos es un cuerpo inerte

Es evidente que hay una conexión entre el hombre-masa de las grandes urbes europeas y el declinar de esta civilización. A una escala agigantada, las masas desarraigadas de la ciudad aspiran a un sustento público garantizado bajo amenaza de amotinamientos y caos. Pero su violencia ya no tiene "letra": el Manifiesto Comunista ni ningún otro texto (ni catecismo, ni panfleto) no guían su acción. En ocasiones, estos estallidos violentos no pretenden derribar el orden social con vistas a sustituirlo por otro nuevo. Entre ellos no hay un Lenin ni una vanguardia del proletariado: no puede haberlo. Los estallidos violentos del hombre masa anhelan castigo, reforzamiento del propio orden que viola, blindaje de las autocracias. Parecen emanados de esa necesidad masoquista en la que hay que hacerse notar para ser aplastados intermitentemente. París y sus revueltas de los barrios marginales, los disturbios recientes de Londres. Todo este universo oscuro de la Europa multiétnica está siendo muy pobremente analizado. Entre un racismo pedestre y popular, una xenofobia espontánea, y el jacobinismo de la santa madre economía que dicta "que las causas residen en la pobreza y la marginación", se encuentran muchas otras posibilidades explicativas. Como Spengler no es un filósofo oficial en ninguna parte, y antes bien es un maldito entre los bienpensantes, no ha servido de inspirador de análisis que señalen nuestra profunda decadencia como Occidentales. Si un extranjero muy distante, un extraterrestre, quisiera hacerse con una pronta imagen de qué es lo europeo, no se encontraría con las reuniones de euroburócratas encorbatados, ni con selectos espectadores de una ópera. Antes bien, lo "europeo" tiene que ser ahora parte de otro cuadro: las masas vociferantes de un estadio de futbol, con sus caras pintadas como los salvajes, así como los saqueadores de la City en el verano de 2011. 